\title{
RELATIONSHIP OF SEMINAL FRUCTOSE AND SERUM PROLACTIN LEVELS IN INFERTILE MEN
}

\author{
JUHI KATARIA ${ }^{1 *}$, GURPREET KAUR GILL ${ }^{1}$, LOUIS COJANDARAJ ${ }^{2}$
}

${ }^{1}$ Department of Medical Laboratory Sciences, Khalsa College of Pharmacy and Technology, Amritsar, Punjab, India. ${ }^{2}$ Department of Medical Laboratory Sciences, Lovely School of Allied Medical Sciences, Lovely Professional University, Phagwara, Punjab, India Email: kataria_juhi@yahoo.in

Received: 17 August 2021, Revised and Accepted: 27 September 2021

\section{ABSTRACT}

Objective: Male infertility refers to a male's inability to cause pregnancy in a fertile female. Infertility is a widespread problem for about one in five infertile couples. Male infertility is usually caused by a problem that affects either sperm production or sperm transport. The aim of the study was to evaluate prolactin levels in the serum and comparing the levels of fructose in the semen of infertile males and normal healthy controls of reproductive age of 20-45 years respectively.

Methods: Hemoglobin $(\mathrm{Hb})$ level in the blood of both groups was calculated by Sahli's method using Sahli's Hemoglobinometer. The Erythrocyte Sedimentation Rate (ESR) was determined using the modified Westergren's method and total leukocyte count (TLC) in the blood was determined by microdilution method. Semen analysis was performed by the method specified in the World Health Organization Laboratory Manual. Morphology and motility of sperm and their counts were determined by microscopy. Fructose drop test in semen was estimated colorimetrically by the Semen Fructose Estimation Kit and determination of serum prolactin involved the use of Electrochemiluminescence immunoassay using Cobas e 411 analyzer.

Results: $\mathrm{Hb}$ in infertile males was less than healthy controls. However, ESR in infertile men was considerably high and TLC, serum prolactin levels did not show much variation in infertile men. Seminal analysis of infertile men revealed high fructose levels and low sperm count with decreased motility.

Conclusion: The concentration of seminal fructose in control group is lower than infertile males. High fructose levels in infertile men and less sperm count indicate oligozoospermia.

Keywords: Infertility, Motility, Semen analysis, Fructose, Erythrocyte sedimentation rate.

(c) 2021 The Authors. Published by Innovare Academic Sciences Pvt Ltd. This is an open access article under the CC BY license (http://creativecommons.org/ licenses/by/4.0/) DOI: http://dx.doi.org/10.22159/ajpcr.2021v14i11.42909. Journal homepage: https://innovareacademics.in/journals/index.php/ajpcr

\section{INTRODUCTION}

Infertility is an extensive health problem affecting the globe. In India, $50 \%$ of the infertility reasons lies in male partners [1]. According to the estimation of the World Health Organization (WHO) 60-80 million couples are suffering from infertility [2]. Infertility is defined as the biological inability to conceive even after 12 months of regular sexual activity [3]. Assessment of fertility capability of male accomplice has become an essential component to achieve pregnancy, however, in maximum instances male denies for the testing of their biological fluid and that consequences in not on time being pregnant. Male infertility refers to a male's inability to cause pregnancy in a fertile female. For approximately one in five infertile couples, the hassle lies within side the male partner. Infertility in males is usually caused by a problem that affects either sperm production or sperm transport and is generally characterized by dysfunctions in the processes of penetration, adhesion, and fusion of sperm with the oocyte [4]. There is a positive association between the abnormal semen parameters and sperm count on which clinical diagnosis depends. Man's infertility is classified mainly into three types: normozoospermic (sperm concentration $\geq 15$ billion/ml), oligozoospermia (sperm concentration $<15$ billion $/ \mathrm{ml}$ ), and azoospermia (no sperm). The most significant of these are low sperm concentration (oligospermia), poor sperm motility (asthenospermia), and abnormal sperm morphology (teratospermia). About $90 \%$ of male infertility problems are related to counting. Abnormal semen parameters and sperm count are positively associated. There may be a lot of reasons for male factor infertility and apart from analyzing semen count, evaluation of seminal fructose and serum prolactin levels is also important. Fructose is produced by the seminal vesicles and its role is to supply energy to the spermatozoa [5]. It has been recommended as a pivotal marker for the evaluation of androgen activity. Several investigators have reported that an increased concentration of sperms is usually amid a lower amount of fructose in seminal plasma [6]. Fructose is the major glycolysable substrate of seminal plasma and is broadly accepted as a vesicle function marker $[7,8]$. However, others consider that fructose content was not diminished in seminal plasma of patients with oligospermia and azoospermia as compared to healthy control [9]

Determination of the relationship between serum prolactin level and semen analysis is additionally crucial for male factor infertility. Marked differences within the content of semen are often seen in hyperprolactin male as compared to normal healthy controls [10]. Prolactin is a hormone for metabolizing energy of human sperm. Elevated concentration of this hormone features a negative impact on man's fertility. Researchers have found that range above normal can impairs fertility by lowering the number of sperms [11] but some researches have not found any correlations among serum prolactin levels and count of sperms [12]. Numerous studies are done to see the effect of serum prolactin and seminal fructose on various parameters of semen, our study aimed toward evaluating erythrocyte sedimentation rate (ESR) within the blood, prolactin levels in the serum and comparing the amount of fructose in the semen of infertile males and normal healthy controls of reproductive age and to seek out the effect of serum prolactin on sperm motility and sperm concentration.

\section{METHODS}

In this study, total 40 subjects were investigated including healthy and infertile males of reproductive age within a range of $20-45$ years visiting Dr. Kulvinder Kaur Centre for Human Reproduction and Infertility Centre, Jalandhar (Punjab). 20 fertile males of similar age were considered as 
controls. Inclusion criteria were age between 20 and 45 years males with abstinence period of 4-5 days. An exclusion criterion was the presence of any urogenital infection. The study was categorized into two groups', namely, healthy controls and infertile males. The ethical and research committee of the diagnostic laboratory approved the study protocol and informed consent was obtained from the patients before the collection of the blood and semen samples. For the collection of seminal samples, subjects were instructed for sexual abstinence of about 4-6 days. The blood samples were obtained after overnight fasting and immediately after blood sample collection the subject was asked to collect semen samples by masturbation. Mean age and weight of the two groups', that is, healthy controls and infertile males were calculated. Hemoglobin $\mathrm{Hb}$ level in the blood of both groups was calculated by Sahli's method using Sahli's Hemoglobinometer [13]. The ESR was determined using the modified Westergren' method [14] and total leukocyte count (TLC) in the blood was determined by microdilution method [15]. Semen analysis was done within $2 \mathrm{~h}$ after the ejaculation by the method specified in WHO Laboratory Manual (2010) [16]. The fructose drop test in semen was estimated colorimetrically by the Semen Fructose Estimation Kit [16]. Determination of serum prolactin involved the use of Electrochemiluminescence immunoassay using Cobas e 411 analyzer [17]. Data were calculated and represented in the form of mean \pm standard deviation.

\section{RESULTS}

The mean age and weight of healthy controls and infertile males are depicted in Table 1 . The mean age of study participants was $30.65 \pm 4.0$ and $32.1 \pm 6.25$ years, respectively, and the mean weight of healthy controls was slightly lower $72.4 \pm 6.5 \mathrm{~kg}$ than infertile males $77.25 \pm 8.75 \mathrm{~kg}$.

In the present study, $\mathrm{Hb}$ levels in infertile males were $12.21 \pm 1.35 \mathrm{~g} / \mathrm{dl}$ and $13.00 \pm 0.73 \mathrm{~g} / \mathrm{dl}$ in healthy controls (Table 2) which was the same. ESR in infertile males was considerably high $(22.5 \pm 10.03 \mathrm{~mm} / \mathrm{h})$ as compared to healthy controls $(8.55 \pm 2.71 \mathrm{~mm} / \mathrm{h})$. TLC levels did not show much variation in infertile males' $7212 \pm 2389 \mathrm{cu} / \mathrm{mm}$ and healthy controls $7870 \pm 1389 \mathrm{cu} / \mathrm{mm}$. The number of cells was found to be lesser in infertile males as compared to healthy controls.

The semen analysis revealed characteristics of sperms in both the groups under study (Table 3). Sperm count was very low in infertile

Table 1: Age and weight of healthy controls and infertile males

\begin{tabular}{lll}
\hline Subjects & Age (years) & Weight $(\mathbf{k g})$ \\
\hline Healthy controls & $30.65 \pm 4.0$ & $72.4 \pm 6.5$ \\
Infertile males & $32.1 \pm 6.25$ & $77.25 \pm 8.75$ \\
\hline
\end{tabular}

Mean \pm SD

Table 2: Hematological parameters of healthy and infertile males

\begin{tabular}{llll}
\hline Subjects & Hb $(\mathbf{g} / \mathbf{d l})$ & TLC $(\mathbf{c u} / \mathbf{m m})$ & ESR $(\mathbf{m m} / \mathbf{h})$ \\
\hline Healthy controls & $13.00 \pm 0.73$ & $7870 \pm 1389$ & $8.55 \pm 2.71$ \\
Infertile males & $12.21 \pm 1.35$ & $7212 \pm 2389$ & $22.5 \pm 10.03$ \\
\hline
\end{tabular}

Mean \pm SD

Table 3: Semen analysis and serum prolactin levels of healthy controls and infertile men.

\begin{tabular}{llll}
\hline Subjects & $\begin{array}{l}\text { Total Sperm } \\
\text { Count } \\
\text { (million/ml) }\end{array}$ & $\begin{array}{l}\text { Semen } \\
\text { fructose } \\
\text { (mg/dl) }\end{array}$ & $\begin{array}{l}\text { Serum prolactin } \\
\text { (ng/dl) }\end{array}$ \\
\hline $\begin{array}{l}\text { Healthy controls } \\
\text { Infertile males }\end{array}$ & $\begin{array}{l}85.35 \pm 9.63 \\
28.45 \pm 5.85\end{array}$ & $\begin{array}{l}189.45 \pm 23.9 \\
200 \pm 20.72\end{array}$ & $\begin{array}{l}10.05 \pm 3.63 \\
9.9 \pm 3.87\end{array}$ \\
\hline Mean + SD & & &
\end{tabular}

males $(28.45 \pm 5.85$ million $/ \mathrm{ml})$ as compared to the healthy controls $(85.35 \pm 9.63$ million $/ \mathrm{ml})$. Semen fructose levels were higher in infertile males $(200 \pm 20.72 \mathrm{mg} / \mathrm{dl})$ as compared to healthy controls $(189.45 \pm 23.9 \mathrm{mg} / \mathrm{dl})$. Fructose is required for vitality and motility, and an increased concentration of sperms requires more fructose resulting in decreased concentration in semen. However, it has been observed that due to low sperm count, the utilization of fructose is less and its concentration in semen might have increased in the semen. Serum prolactin levels in healthy controls and infertile males were $10.05 \pm 3.63 \mathrm{ng} / \mathrm{dl}$ and $9.9 \pm 3.87 \mathrm{ng} / \mathrm{dl}$, respectively.

\section{DISCUSSION}

In infertile male, the ESR has been found significantly higher as compared to healthy controls, which indicated inflammation. The inflammation might be within the male's reproductive tract and a number of causes of this include duct obstruction, urethritis, epididymitis, which can end in further complications such as scrotal swelling, pain, penile discharge, and blood in the urine. When any of these processes occurred in the male's genital tract, the immune system might have responded to pathogens and possible tissue damage. As inflammation is the process of responding to injury and tissue damage, this process bought leukocytes and plasma molecules to the site of infections. There is an increase in the migration of leukocytes into the tissues [18]. Thus, in the present study, this has been observed that TLC in blood has been found lesser in infertile males as compared to healthy controls. In this study, there was a significant difference in total sperm count between the two study groups. Total sperm count was lesser in the infertile group as compared to the fertile group. Normal concentration of seminal fructose indicates that testosterone, vesicles and vas deferens are normal. In the present study, the semen fructose levels were lower in healthy controls as compared to infertile males. In normozoospermia, the concentration of fructose is lower because the sperm utilize fructose for progressive motility and vitality. The increased concentration of sperms and vitality is inversely proportional to the fructose concentration in semen [19]. In the cases where sperm count becomes too high, the seminal fructose decreases to lower than normal levels [20]. However, in oligozoospermia, the fructose concentration increases, as it remains unutilized. Our findings found the correlation of decreased total sperm count and increased seminal fructose in infertile males which is in line with the study of Gonzales (2001) [6] and Orakwe et al. (2010) [21]. The decrease in the total sperm count might be due to reduced spermatogenesis. Diminished spermatogenesis elevates pituitary-produced gonadotrophins [22]. The pituitary gland secretes hormones that signal the reproductive organs to make sex hormones. The male reproductive system is controlled by the action of prolactin on the pituitary gland by binding to specific sites. Although prolactin stimulates the formation of steroids and can have effects on the spermatogenesis, individuals with defective spermatogenesis may have serum prolactin levels within the normal limits [23]. Our finding also corroborates with the same. Insignificant variations in the levels of serum prolactin were found in both the study groups. The serum prolactin levels were found to be in the normal range and the concentration of sperm and serum prolactin levels were not related to each other. As human sperms actively utilize fructose for their fertilizing capacity and vitality, prolactin has a stimulatory effect on this active utilization but in our findings, no relationship was found between seminal fructose and serum prolactin levels in infertile males and healthy controls.

\section{CONCLUSION}

Higher concentration of seminal fructose and decreased sperm count in infertile men showed oligozoospermia. Less utilization of fructose due to decreased sperm count may reflect abnormality in the role of testosterone, vesicles, and vas deferens. Serum prolactin levels showed a negative relationship with seminal fructose in different groups. This could lead to the fact that male infertility may include multiple factors in spite of seminal fructose and serum prolactin. 


\section{AUTHOR'S CONTRIBUTION}

All authors contributed to the collection of samples, conducting and analysing the experiments, evaluating the results, writing and finalizing the article.

\section{CONFLICTS OF INTEREST}

There are no conflicts of interest.

\section{AUTHOR'S FUNDING}

Nil.

\section{REFERENCES}

1. Kumar TA. In vitro fertilization in India. Curr Sci 2004;86:254-6.

2. Calverton M. USA: ORC Macro and the World Health Organization. World Health Organization. Infecundity, Infertility, and Childlessness in Developing Countries. Kerala: DHS Comparative Reports; 2004.

3. Kamel RM. Management of the infertile couple: An evidence-based protocol. Reprod Biol Endocrinol 2010;8:1-7.

4. Zegers-Hochschild F, Adamson GD, de Mouzon J, Ishihara O, Mansour R, Nygren $\mathrm{K}$, et al. The international committee for monitoring assisted reproductive technology (ICMART) and the World Health Organization (WHO) revised glossary on ART terminology. Hum Reprod 2009;24:2683-7.

5. Schoenfeld CY, Amelar RD, Dubin L, Numeroff M. Prolactin, fructose, and zinc levels found in human seminal plasma. Fertil Steril 1979;32:206-8.

6. Gonzales GF. Function of seminal vesicles and their role on male fertility. Asian J Androl 2001;3:251-8.

7. Ndovi TT, Choi L, Caffo B, Parsons T, Baker S, Zhao M, et al. Quantitative assessment of seminal vesicle and prostate drug concentrations by use of a noninvasive method. Clin Pharmacol Ther 2006;80:146-58

8. Raj V, Vijayan AN, Joseph K. Naked eye detection of infertility using fructose blue-a novel gold nanoparticle based fructose sensor. Biosens Bioelectron 2014;54:171-4.

9. Buckett WM, Lewis-Jones DI. Fructose concentrations in seminal plasma from men with nonobstructive azoospermia. Arch Androl
2002;48:23-7.

10. Ahmed ND, Ahmed HS. The relationships between serum prolactin level and semen analysis parameters among patients attended the reproductive health center, Khartoum 2016-2017. Sudan Med Monit 2017; $12: 41-4$

11. Luboshitzky R, Rosen E, Trestian S, Spitz IM. Hyperprolactinaemia and hypogonadism in men: Response to exogenous gonadotrophins. Clin Endocrinol News 1979;11:217-23.

12. Okada H, Iwamoto T, Fujioka H, Shirakawa T, Tatsumi N, Kanzaki M, et al. Hyperprolactinaemia among infertile patients and its effect on sperm functions. Andrologia 1996;28:197-202.

13. Berman L. The determination of hemoglobin by the acid hematin method. Arch Intern Med 1919;24:553-6.

14. Zhao TX, Lockner D. Electrical impedance and erythrocyte sedimentation rate (ESR) of blood. Biochim Biophys Acta Biomembr 1993;1153:243-8.

15. Blumenreich MS. The white blood cell and differential count. In: Clinical Methods: The History, Physical, and Laboratory Examinations. $3^{\text {rd }}$ ed. Boston: Butterworths; 1990. p. 153-77.

16. Menkveld R. Clinical significance of the low normal sperm morphology value as proposed in the fifth edition of the WHO laboratory manual for the examination and processing of human semen. Asian J Androl 2010;12:47-58.

17. Sánchez-Carbayo M, Mauri M, Alfayate R, Miralles C, Soria F. Analytical and clinical evaluation of TSH and thyroid hormones by electrochemiluminescent immunoassays. Clin Biochem 1999;32:395-403.

18. Nourshargh S, Alon R. Leukocyte migration into inflamed tissues. Immunity 2014;41:694-07.

19. Lu JC, Chen F, Xu HR, Huang YF, Lu NQ. Standardization and quality control for determination of fructose in seminal plasma. J Androl 2007;28:207-13

20. Kumar N, Singh AK. Trends of male factor infertility, an important cause of infertility: A review of literature. J Hum Reprod 2015;8:191-6.

21. Orakwe JC, Chukwuezi FO, Ebuh GU. True corrected seminal fructose in male infertility in Nigerians a preliminary study. Niger J Clin Pract 2010;13:84-6.

22. Tüttelmann F, Ruckert C, Röpke A. Disorders of spermatogenesis. Med Genet 2018;30:12-20.

23. Hermanns U, Hafez ES. Prolactin and male reproduction. Arch Androl 1981;6:95-125. 